\title{
Industrial trial to produce a low clinker, low carbon cement
}

\author{
L.M. Vizcaíno-Andrés ${ }^{\mathrm{a}}$, S. Sánchez-Berriel ${ }^{\mathrm{a}}$, S. Damas-Carrera ${ }^{\mathrm{b}}$, \\ A. Pérez-Hernández ${ }^{c}$, K.L. Scrivener ${ }^{\mathrm{d}}$, J.F. Martirena-Hernández ${ }^{\mathrm{a}} \bowtie$ \\ a. Center for the Research and Development of Structures and Materials (CIDem), \\ Central University "Marta Abreu" of Las Villas (UCLV), (Villa Clara, Cuba) \\ b. Siguaney Cement Factory, Cement Enterprise Group (GECEM) (Siguaney, Sancti Spíritus, Cuba) \\ c. Technical Center for the Development of Construction Materials, Ministry of Construction, (La Habana, Cuba) \\ d. École Polytechnique Fédérale de Lausanne (EPFL), (Lausanne, Switzerland) \\ $\bowtie$ f.martirena@enet.cu
}

\author{
Received 24 January 2014 \\ Accepted 18 June 2014 \\ Available on line 29 January 2015
}

\begin{abstract}
A preliminary assessment of conditions for the industrial manufacture of a new cementitious system based on clinker-calcined clay and limestone, developed by the authors, referred as "low carbon cement" is presented. The new cement enables the substitution of more than $50 \%$ of the mass of clinker without compromising performance. The paper presents the follow-up of an industrial trial carried out in Cuba to produce 130 tonnes of the new cement at a cement plant. The new material proved to fulfill national standards in applications such as the manufacture of hollow concrete blocks and precast concrete. No major differences either in the rheological or mechanical properties were found when compared with Portland cement. Environmental assessment of the ternary cement was made, which included comparison with other blended cements produced industrially in Cuba. The new cement has proven to contribute to the reduction of above $30 \%$ of carbon emissions on cement manufacture.
\end{abstract}

KEYWORDS: Cement; Calcined clays; Energy; Emissions; Production

Citation/Citar como: Vizcaíno-Andrés, L.M.; Sánchez-Berriel, S.; Damas-Carrera, S.; Pérez-Hernández, A.; Scrivener, K.L.; Martirena-Hernández, J.F. (2015) Industrial trial to produce a low clinker, low carbon cement. Mater. Construcc. 65 [317], e045 http://dx.doi.org/10.3989/mc.2015.00614.

RESUMEN: Impacto del uso de un cemento de bajo carbono en la mejora de la sostenibilidad de la producción de cemento. Se presenta la evaluación preliminar de las condiciones de fabricación industrial de un nuevo sistema cementicio a partir del empleo de clínquer; arcillas calcinadas y piedra caliza; desarrollado por los autores; denominado "cemento de bajo carbono". El nuevo cemento posibilita la reducción de más de un 50\% de la masa de clínquer; sin comprometer el comportamiento del material. El presente trabajo presenta el monitoreo de la producción industrial en una planta en Cuba; de 130 t del nuevo cemento. El cemento obtenido cumple con las regulaciones nacionales de calidad y su empleo tiene similar rendimiento que el cemento Pórtland para la producción de bloques y hormigón de $25 \mathrm{MPa}$. Se realiza el análisis de impacto ambiental del cemento ternario mediante la comparación con otros cementos producidos industrialmente. El nuevo cemento puede contribuir a la reducción de más del 30\% de las emisiones de $\mathrm{CO}_{2}$ asociadas a la manufactura de cemento.

PALABRAS CLAVE: Cemento; Arcillas calcinadas; Energía; Emisiones; Producción

Copyright: (C) 2015 CSIC. This is an open-access article distributed under the terms of the Creative Commons Attribution-Non Commercial (by-nc) Spain 3.0 License. 


\section{INTRODUCTION}

The amount of cement produced in 2011 was 3.6 billion of tonnes (1). If average content of cement per $\mathrm{m}^{3}$ of concrete ranges around $250 \mathrm{~kg}$ of cement; approximately 14 billion of $\mathrm{m}^{3}$ of concrete were made only in this year; this is equivalent to approximately $2 \mathrm{~m}^{3}$ of concrete for every inhabitant of planet Earth. No other material is produced in these massive quantities (2).

Approximately $5-9 \%$ of anthropogenic total emissions of $\mathrm{CO}_{2}$ are related to the concrete production. This is caused by the massive production and use of cement in the construction sector; $85 \%$ of concrete emissions are associated with cement manufacture; thus its contribution is approximately $3-5 \%$ of global $\mathrm{CO}_{2}$ emission $(3,4)$. Any improvement in cement manufacture may have a great impact on the reduction of $\mathrm{CO}_{2}$ released to the atmosphere.

Tackling the urgent housing problems in development countries prompts for the massive availability of construction materials. The demand of cement is projected to double by 2050; and most of this increase will come from development countries; in which infrastructure is not been developed yet; and the growth of population will put pressure on expansion of existing urban areas (5).

The cement manufacture process includes burning the raw materials at very high temperatures to produce clinker. Depending on the type of process used; the energy consumption can be between 3000-6500 MJ/tonne of clinker (6). Greenhouse gases are released during cement manufacture; among them $\mathrm{CO}_{2}$. Calcium carbonate represents approximately $72-78 \%$ of all raw materials used for clinker manufacture; the main component of cement. At around $900{ }^{\circ} \mathrm{C}$; calcium carbonate turns into calcium oxide and releases 0.44 ton of $\mathrm{CO}_{2}$ to the atmosphere per each tonne of calcined material; this represents approximately $60 \%$ of the $\mathrm{CO}_{2}$ released during cement manufacture. The rest of $\mathrm{CO}_{2}$ emitted comes from the fuel used in the firing process and the electricity used for grinding (3). Depending on the efficiency of the kiln; the rate of emission of cement production ranges between 0.67-1.00 tonnes $\mathrm{CO}_{2} /$ tonne cement (2).

A strategy for a higher reduction of $\mathrm{CO}_{2}$ emissions during cement manufacture may be to reduce the amount of clinker used; for it is the main responsible of $\mathrm{CO}_{2}$ emissions. This can be attained through the use of Supplementary Cementitious Materials (SCM) as clinker substitutes. However; the current substitution rate for most cement industries is around 30\%; which is not sufficient enough to drastically reduce the global carbon emissions associated with cement manufacture (5). Further; the availability of suitable SCMs is limited and it is closely related with industrial development; which considerably affects developing countries (7).

The authors of this paper have developed a new cementitious system that increases clinker substitution to $50 \%$ without significantly influencing cement performance. The new system is based on the synergy between the aluminates supplied by calcined kaolinite clay and the carbonates from limestone; which enhances the pozzolanic reaction of the calcined clay; and thus enables a higher clinker substitution rate $(8,9)$. The $\mathrm{CO}_{2}$ emissions associated to clinker are considerably reduced in the new system; and the $\mathrm{CaCO}_{3}$ added to the system is not calcined; thus no extra $\mathrm{CO}_{2}$ is not released to the atmosphere; this justifies the label "low carbon cement" (LCC) given to the cement.

The two SCMs used in the new system; calcined clay and limestone have a higher availability than other SCMs. Low grade kaolinite clay has proven to be a suitable alternative to the pure kaolinite metakaolin (MK) currently used by the industry (10). Low grade kaolinite clay reserves are huge and are better geographically distributed than pure kaolinite clay deposits. The size of limestone reserves is in the same order of magnitude as current world cement production (7).

This article presents the results of an industrial trial carried out at a cement plant in Cuba for the production of the new cement at industrial scale. Comparisons between industrial and lab results were made. Further; a preliminary environmental assessment of the production of the new cement was done; which included a comparison with cements produced industrially in Cuba.

\section{CLINKER SUBSTITUTION RATE AT BLENDED CEMENTS VS. TERNARY BLEND CEMENTS}

Pozzolans are been extensively used as SCM to substitute clinker in cement production. They react as described below -for silica rich pozzolanic systems- $(11,13),[1]$ :

$$
\mathrm{S}+1.5 \mathrm{CH} \quad+2.8 \mathrm{H} \Rightarrow \mathrm{C}_{1.5} \mathrm{SH}_{2.8}
$$

silica+calcium hydroxide+water $\Rightarrow$ calcium silicate hydrate

The amount of clinker than can be substituted by pozzolans depends on the availability of calcium hydroxide produced during cement hydration. In pure silica pozzolanic systems; for substitution ratios above $15 \%$ wt.; calcium hydroxide produced during hydration is not sufficient to react with all the pozzolanic material (see Table 1); and thus; the unreacted material performs like a filler (13). Higher replacement levels can compromise the mechanical properties of the binder as kinetics of the pozzolanic reaction is usually slower than in pure clinker systems. For this reason most of cement producers 
TABLE 1. Relation between clinker substitution and portlandite availability in the blended cement

\begin{tabular}{lcccc}
\hline Compounds & $\begin{array}{c}\text { Cement no } \\
\text { replacement }\end{array}$ & $\begin{array}{c}\text { Cement 15\% } \\
\text { replacement }\end{array}$ & $\begin{array}{c}\text { Cement 20\% } \\
\text { replacement }\end{array}$ & $\begin{array}{c}\text { Cement 25\% } \\
\text { replacement }\end{array}$ \\
\hline Available calcium hydroxide & $27.0 \mathrm{~g}$ & $23.0 \mathrm{~g}$ & $21.6 \mathrm{~g}$ & $20.3 \mathrm{~g}$ \\
Pozzolan & $0.0 \mathrm{~g}$ & $15.0 \mathrm{~g} *$ & $20.0 \mathrm{~g} *$ & $25.0 \mathrm{~g} *$ \\
Calcium hydroxide needed for a complete reaction* & $0.0 \mathrm{~g}$ & $19.4 \mathrm{~g}$ & $25.9 \mathrm{~g}$ & 32.4 \\
\hline
\end{tabular}

*Calculated by the authors considering that $70 \%$ of pozzolan reacts.

limit the clinker replacement up to approximately $25-35 \%$ wt.

Metakaolin (MK) $\left(\mathrm{Al}_{2} \mathrm{Si}_{2} \mathrm{O}_{7}\right)$ is a highly reactive pozzolan produced through the calcination of clays rich in kaolinite mineral. The reactivity of MK depends on several factors; such as temperature; rate of heating and cooling regimen. The optimal temperature of calcination is between $700-800{ }^{\circ} \mathrm{C}$; although the dehydroxylation of the clay is known to begin at $500{ }^{\circ} \mathrm{C}(14)$.

The pozzolanic reaction of MK with the calcium hydroxide $(\mathrm{CH})$ in pastes is described as follows $(15,16)[2]:$

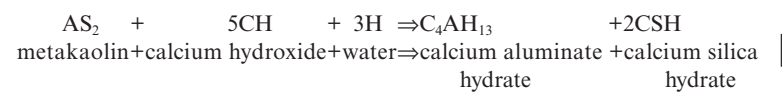

Metakaolin is rich in alumina; so its use as SCM increases the volume of new alumina phases in the system. If calcium carbonate is introduced in the system through an external source; for example; limestone; the alumina phases react with it to form the following compounds $(8),[3,4]$ :

$$
\begin{aligned}
& \text { Hemicarboaluminate } 3 \mathrm{CaO} \cdot \mathrm{Al}_{2} \mathrm{O}_{3} \\
& 0.5 \mathrm{Ca}(\mathrm{OH})_{2} \cdot 0.5 \mathrm{CaCO}_{3} \cdot 11.5 \mathrm{H}_{2} \mathrm{O}
\end{aligned}
$$

$$
\text { Monocarboaluminate } 3 \mathrm{CaO} \cdot \mathrm{Al}_{2} \mathrm{O}_{3} \cdot \mathrm{CaCO}_{3} \cdot 11 \mathrm{H}_{2} \mathrm{O}
$$

Based on this principle; it is possible to replace a mass of clinker by a similar mass of MK and calcium carbonate mixed in a 2:1 ratio; respectively; to form hydration products; which are able to fill the pore system of the cement matrix and contribute to the strength. Experimental laboratory results (8) show that it is possible to replace up to $45 \%$ wt. of clinker without compromising compressive strength of the material. For $60 \%$ of replacement; $90 \%$ of strength -related to plain cement- can be reached. The alumina phases react faster; so the early strength is not substantially affected (9).

\section{LOW CARBON CEMENT}

The low carbon cement developed is produced by using the ternary systems of clinker-calcined clays and limestone described above. Medium purity kaolinite clay has proven to be a good alternative to MK in this system; thus increasing the availability and reducing production cost of the cement. The limestone introduced to the system is not calcined; thus no extra $\mathrm{CO}_{2}$ is emitted to the environment $(8,9)$.

There are already reports of such an approach for ternary Portland limestone blends with alumina rich pozzolans. De Weert et al. (17) and Moesgaard et al. (18) have worked in fly ashlimestone-Portland cement systems; and they have reported an increase of the mechanical properties caused by the synergy between the fly ash and limestone; which favors the formation of carboaluminate phases that provide a beneficial contribution of the performance of the system. Antoni et al. (8) have worked on similar systems; and the synergy established between the Metakaolin and limestone; as well as its contribution to improving the mechanical properties of cementitious systems with high level of clinker substitution has been proven.

Figure 1 a) compares the different alternatives for blended cements and ternary blends at 7 days. The ternary blend cements; with higher clinker substitution rates achieve higher early strength than ordinary blended cements produced with different sources of pozzolan. This trend remains at later ages as presented in Figure $1 \mathrm{~b}$ ).

\section{PROOF OF CONCEPT: INDUSTRIAL TRIAL FOR THE MANUFACTURE OF LOW CARBON CEMENT (LCC) IN CUBA}

The very promising results for ternary blends were achieved only at lab scale; under strictly controlled conditions. To scale up this process other considerations have to be taken into account. Significant differences between the procedures used for clay calcination and grinding at lab and industrial scale can take place. A full scale industrial trial was carried out for the production of bulky amounts of cement under real conditions. The Cuban cement industry designated the cement factory Siguaney for the industrial trial.

The target ternary cement should have clinker content around $50 \%$. The trial included the calcination of 110 tonnes of medium grade kaolinitic clay; mixing 

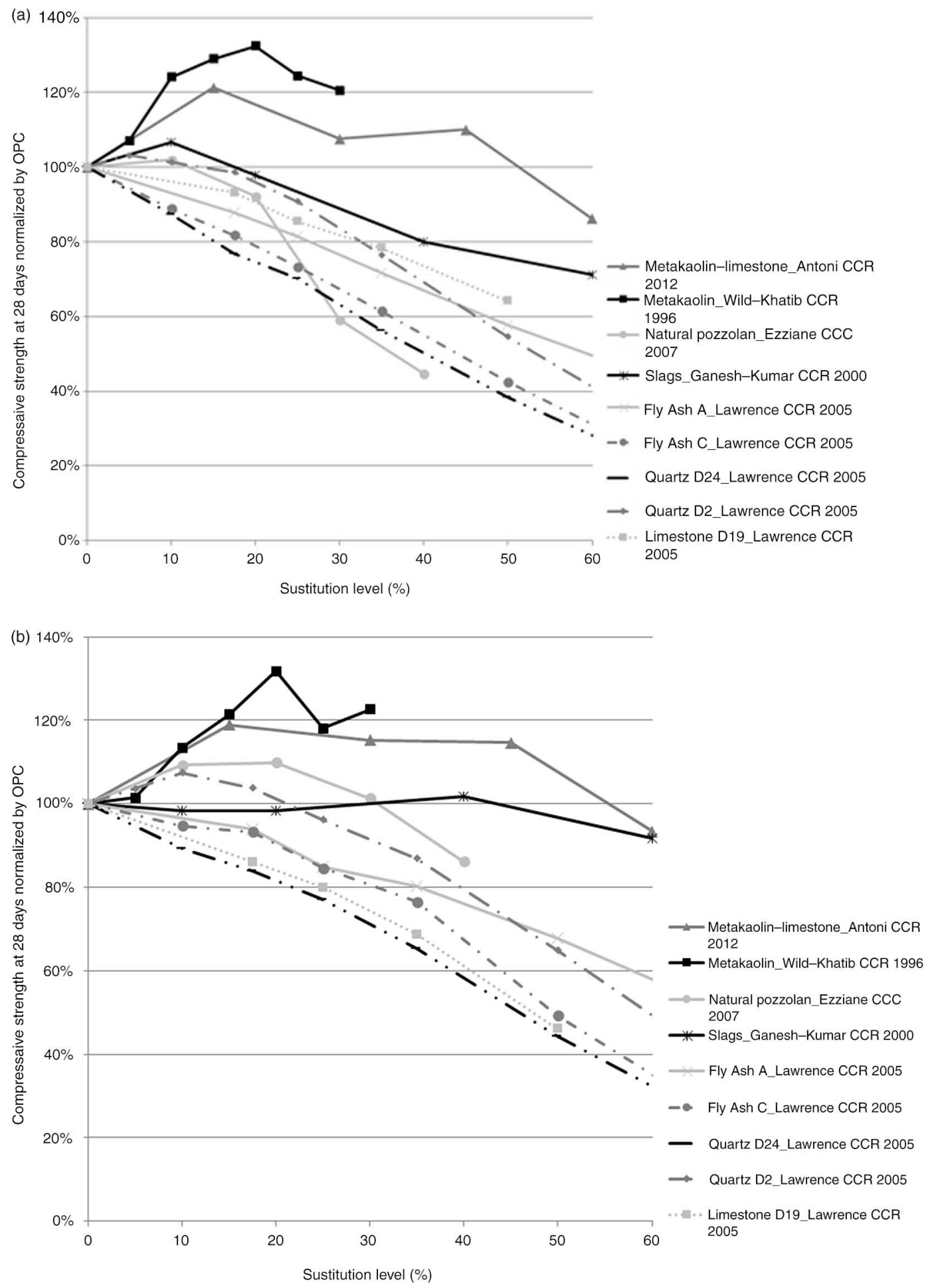

FiguRE 1. Compressive strength of blends made with different SCM and different clinker factors; results are presented for (a) 7 days (b) 28 days $(8,19-22)$.

and homogenizing of the calcined material with limestone in a 2:1 ratio; and co-grinding of the synergetic materials with clinker and gypsum.
For the trial; clay from the clay deposit Pontezuela was selected. The material is classified by the authors as a medium grade kaolinite clay; with an average 
content of kaolinite of $48.6 \%$; measured by thermogravimetric analysis (TGA). Chemical composition for samples of the clay was assessed aided by X- ray fluorescence (XRF); Table 2 presents the results. $\mathrm{X}$-ray diffraction (XRD) confirmed the presence of companion mineral such as quartz and iron.

Calcination implied the modification of a wet process rotary kiln - regularly used for clinker production- in order to calcine the material on dry conditions (Figure 2). The clay was fed to the kiln and then heated to $750^{\circ} \mathrm{C}$; temperature chosen as optimal for calcination of the material $(16,23,24)$.

After the calcination 90 tonnes of calcined material were obtained; the loss of material was associated with moisture content of the original clay; as well as the chemically bound water on the structure of the clay. The calcined material was stored in five heaps.

The quality of calcination was assessed through the dehydroxylation of the calcined clay. The complete dehydroxylation is achieved when all $\mathrm{OH}^{-}$ groups are released during calcination; and the peak associated with this in TGA disappears. Figure 3 presents the individual results for each of the five heaps of calcined material evaluated. All heaps have been completely dehydroxylated; thus indicating that the material has been fully activated.

The pozzolanic reactivity of the calcined material was assessed through the compressive strength of standardized mortars; in which $30 \%$ wt. of cement is replaced by the pozzolanic material; following the protocol of Fernández and Antoni $(8,14)$. Two reference series were prepared with $100 \%$ of ordinary Portland cement (OPC) and cement with 30\% wt. pozzolanic material calcined under optimal conditions at the laboratory. Figure 4 presents the results

TABle 2. Chemical composition of representative samples of Pontezuela clay

\begin{tabular}{lccc}
\hline Oxides & SAMPLE 1 & SAMPLE 2 & SAMPLE 3 \\
\hline $\mathrm{SiO}_{2}$ & 54.7 & 54.2 & 55.0 \\
$\mathrm{Al}_{2} \mathrm{O}_{3}$ & 27.8 & 28.2 & 26.0 \\
$\mathrm{Fe}_{2} \mathrm{O}_{3}$ & 12.1 & 12.3 & 13.4 \\
$\mathrm{CaO}$ & 1.7 & 1.7 & 1.8 \\
$\mathrm{MgO}$ & 0.9 & 0.9 & 1.0 \\
$\mathrm{SO}_{3}$ & 0.0 & 1.4 & 0.7 \\
$\mathrm{Na}_{2} \mathrm{O}$ & 0.3 & 0.3 & 0.3 \\
$\mathrm{~K}_{2} \mathrm{O}$ & 1.5 & 1.6 & 1.6 \\
$\mathrm{TiO}_{2}$ & 0.8 & 0.8 & 0.8 \\
$\mathrm{P}_{2} \mathrm{O}_{5}$ & 0.2 & 0.1 & 0.2 \\
$\mathrm{Mn}_{2} \mathrm{O}_{3}$ & 0.0 & 0.0 & 0.0 \\
$\mathrm{Cr}_{2} \mathrm{O}_{3}$ & 1.6 & - & - \\
$\mathrm{LOI}$ & 10.4 & 10.3 & 9.8 \\
$\mathrm{Humidity}$ & 3.5 & 6.1 & 2.9 \\
\hline
\end{tabular}

of compressive strength of standardized mortars at 3; 7 and 28 days. The reactivity of the material calcined in the rotary kiln (average of batches) proved to be similar to that of the material calcined at the lab; thus indicating that the industrial calcination was successful.

Grinding was made under industrial conditions; by using a ball mill with a double chamber grinding system (see Figure 5). In order to avoid high specific surface; it was decided to grind the material rather on the coarse side. Gypsum was adjusted to optimize the reaction of the alumina phase (8). The original gypsum used had a low purity; thus the relatively large proportion in the cement composition; but the total $\mathrm{SO}_{3}$ content was adjusted to fulfill cement standards. Finally; grinding parameters were set as: $10-12 \%$ retained in the $90 \mu \mathrm{m}$ sieve; specific surface between $4000-5000 \mathrm{~cm}^{2} / \mathrm{g}$ and $\mathrm{SO}_{3}$ up to $3.0 \%$.

Grinding was completed in 8 hours. Samples of the material were taken every approximately 30 minutes.

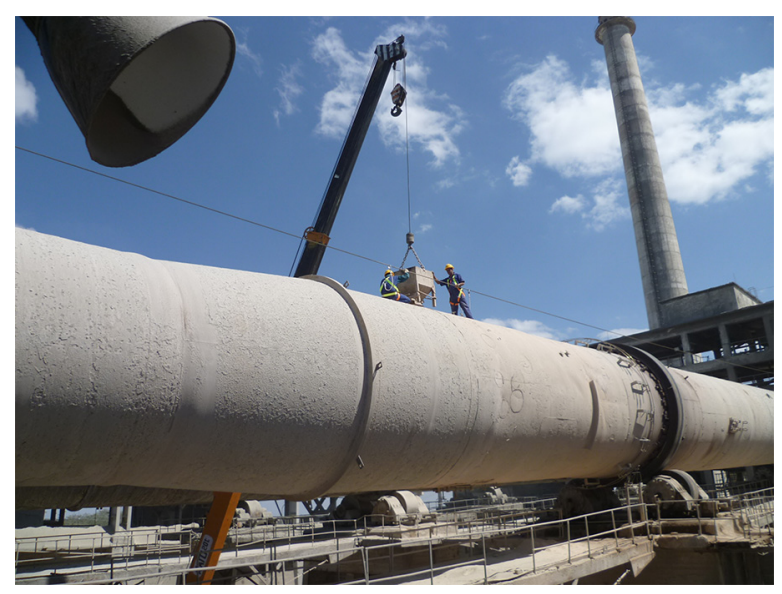

Figure 2. Direct feeding of the clay to the rotatory kiln.

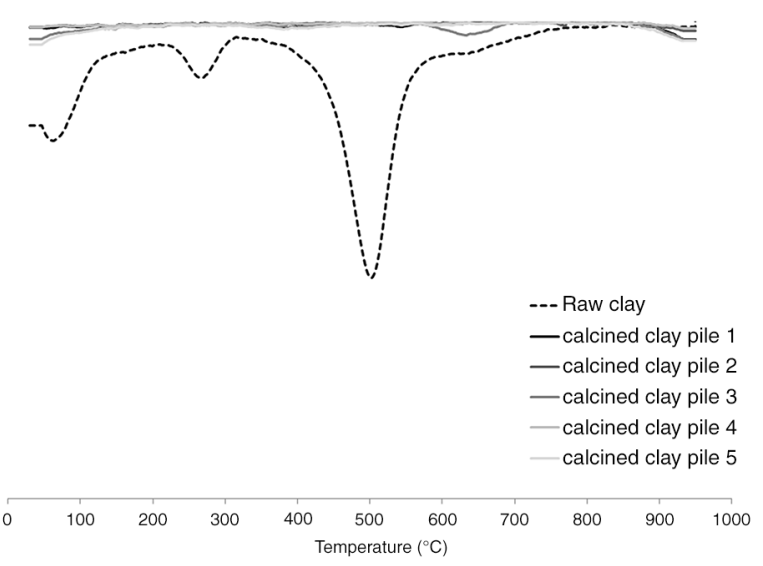

FIGURE 3. Thermo gravimetric analysis of the clay calcined in the rotatory kiln. 


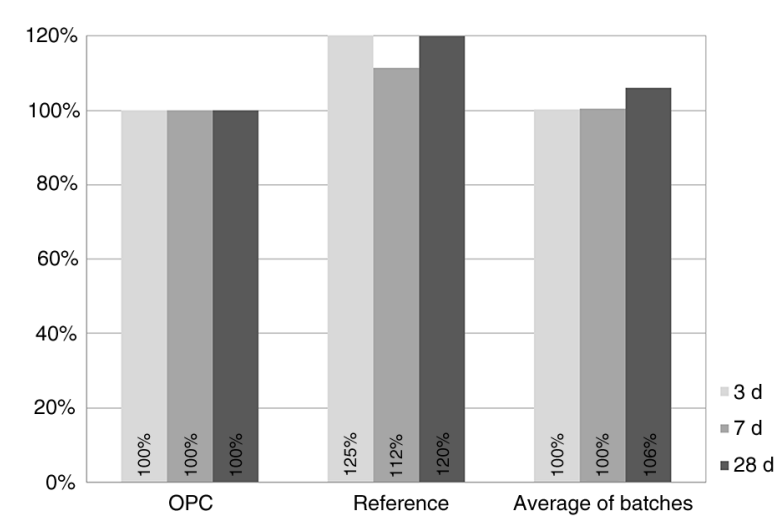

Figure 4. Compressive strength of the cements prepared with $30 \% \mathrm{wt}$. of calcined clay normalized to ordinary Portland cement.

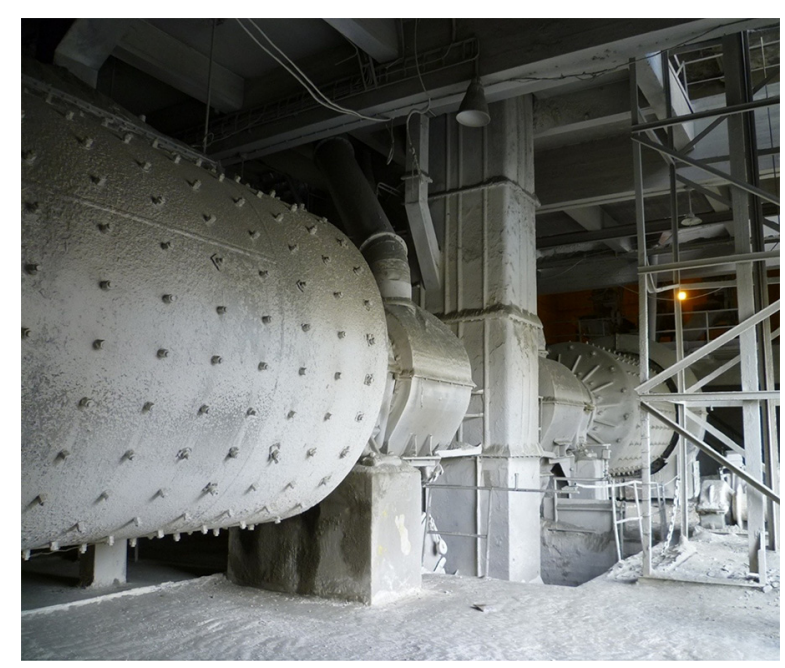

FIGURE 5. Industrial ball mill used to produce; through co-grinding; the low carbon cement.

Table 3 presents the chemical composition of the material obtained and the average proportion of the components.

The final cement was characterized following the protocol established for blended cements in Cuban standards (25-30). Excess grinding of some softer materials through the interaction with other harder ingredients can be produced during the co-grinding process. This can have an influence on the grain size distribution of the cement; and it could eventually increase water demand of the mix (31). Results of the physical and mechanical tests are presented in Table 4.

\section{INDUSTRIAL USE OF THE EXPERIMENTAL CEMENT PRODUCED IN THE INDUSTRIAL TRIAL}

The industrial trial enabled the technical team to sound out the reaction of the construction and manufacturing industry to this new binder. Batches
TABle 3. Chemical composition of industrial low carbon cement

\begin{tabular}{lr}
\hline Chemical compounds & $\%$ \\
\hline $\mathrm{SiO}_{2}$ & 27.3 \\
$\mathrm{Al}_{2} \mathrm{O}_{3}$ & 4.6 \\
$\mathrm{Fe}_{2} \mathrm{O}_{3}$ & 4.6 \\
$\mathrm{CaO}$ & 49.8 \\
$\mathrm{MgO}$ & 1.3 \\
$\mathrm{SO}_{3}$ & 3.7 \\
$\mathrm{IR}$ & 12.6 \\
$\mathrm{LOI}$ & 7.1 \\
$\mathrm{CaO}$ & 0.9 \\
$\mathrm{Total}_{\text {free }}$ & 98.4 \\
& \\
Gypsum & Average proportions of components \\
Calcined clay/Calcium carbonate & 8.9 \\
Clinker & 41.1 \\
\hline
\end{tabular}

of the cement produced were distributed among builders and building material manufacturers; and their use was strictly supervised by the technical team. Potential customers were asked to use the new experimental cement in the same proportions as they usually use the Portland cement.

The trial focused on two main cement applications: (1) manufacture of hollow concrete blocks having size $500 \times 200 \times 150 \mathrm{~mm}$; produced on a semiautomated vibro-compacting machine; and (2) manufacture of $25 \mathrm{MPa}$ precast concrete elements at a prefabrication plant in Cuba. Table 5 presents mix proportions used for both applications. Mix design was accredited by the laboratory of the National Enterprise for Applied Research; in Cuba; following the regulations of Cuban standards (32-36).

Hollow concrete blocks were produced under standard manufacturing conditions; with a 1:1 cement substitution by the new cement. The quality of the blocks was assessed through the Cuban standard NC 247:2010 (37). This standard requires fulfillment of compressive strength and water absorption. Table 6 presents the results of the evaluation of concrete blocks made with the low carbon cement; as well as the reference blocks made with ordinary Portland cement. The experimental blocks met the standard's requirements for compressive strength and water absorption; thus indicating that the new cement can replace Portland cement in this kind of industrial application.

Several cubic meters of $25 \mathrm{MPa}$ concrete were cast under standard manufacturing conditions; with a 1:1 cement substitution by the new cement. Quality of the precast elements produced was assessed aided by the Cuban standards (32-36). Table 7 presents the results of compressive strength of both the experimental and normal concretes cast 
TABLE 4. Results of physical and mechanical test of the industrial low carbon cement

\begin{tabular}{lcccccccc}
\hline & & & \multicolumn{2}{c}{ Setting time } & & \multicolumn{2}{c}{ Compressive strength (MPa) } \\
\cline { 8 - 10 } Material & Retained 4900 Sieve (\%) & Consistency (\%) & Initial (min) & Final (hr.) & Volume Stability (mm) & $\mathbf{3 ~ d ~}$ & $\mathbf{7 ~ d ~}$ & $\mathbf{2 8 ~ d}$ \\
\hline LCC & 12.0 & 25.0 & 135 & 2.9 & 0.3 & 11.0 & 17.5 & 30.3 \\
\hline
\end{tabular}

TABLE 5. Mix proportions used in concrete manufacture

\begin{tabular}{|c|c|c|c|c|}
\hline \multirow{2}{*}{$\frac{\text { For } 1 \mathrm{~m}^{3}}{\text { Materials }}$} & \multicolumn{2}{|c|}{ Gravimetric mix proportion $(\mathrm{kg})$} & \multicolumn{2}{|c|}{ Mix proportion $\left(\mathrm{m}^{3}\right)$} \\
\hline & Hollow block $150 \mathrm{~mm}$ & Concrete $25 \mathrm{MPa}$ & Hollow block $150 \mathrm{~mm}$ & Concrete $25 \mathrm{MPa}$ \\
\hline $\mathrm{LCC}$ & 300 & 360 & 1 & 1 \\
\hline Sand "El Purio" quarry & 654 & - & 1.8 & - \\
\hline Powder "Palenque" quarry & - & 780 & - & 1.6 \\
\hline Aggregates 5-13 mm "El Purio" quarry & 1302 & - & 3.5 & - \\
\hline Aggregates $19-10 \mathrm{~mm}$ "Palenque" quarry & - & 1034 & - & 2.4 \\
\hline Water $(\mathrm{L})$ & 112 & 169 & 0.4 & 0.5 \\
\hline Superplasticizer Dynamon SX-32 (L) & - & 4.0 & - & - \\
\hline w/c batch & 0.4 & 0.5 & - & - \\
\hline w/c effective & 0.2 & 0.4 & - & - \\
\hline Designed slump & 0 & $12 \pm 3 \mathrm{~cm}$ & 0 & $12 \pm 3 \mathrm{~cm}$ \\
\hline
\end{tabular}

TABLE 6. Results of compressive strength and \% absorption of concrete and hollow blocks made with LCC

\begin{tabular}{lcccc}
\hline Dimensions hollow blocks (mm) & $\begin{array}{c}\text { Average compressive } \\
\text { strength at 7 d (MPa) }\end{array}$ & $\begin{array}{c}\text { Average compressive } \\
\text { strength at 28 d (MPa) }\end{array}$ & Performance & \% absorption \\
\hline $500 \times 200 \times 150$ & 3.3 & 5.9 & 2.0 & 5.6 \\
Specification & 4.0 & 5.0 & - & $\leq 10$ \\
\hline
\end{tabular}

for the trial. Both mixes exceed the 28 day strength prescribed; and again; no major differences in rheology were observed; thus indicating that the new cement can replace Portland cement in this kind of industrial application.

\section{ASSESSMENT OF THE ENVIRONMENTAL IMPACT OF THE EXPERIMENTAL CEMENT PRODUCED AT THE INDUSTRIAL TRIAL}

Blended cements with clinker substitution up to $30 \%$ enable reduction of approximately $15-20 \%$ of the $\mathrm{CO}_{2}$ emissions. The new cement formulation presented in this paper enables to increase clinker substitution to $50 \%$ without compromising performance; this represents a reduction of around $30 \%$ of the $\mathrm{CO}_{2}$ emissions associated to the cement manufacture; as Table 8 presents. A preliminary assessment of the environmental impact was made; coupled to the industrial trial at cement factory Siguaney; with the aim of shedding light on the viability of such production from the environmental viewpoint.

Siguaney's clinker manufacturing facilities consist only of wet-process rotary kilns. Because of its low efficiency; the factory is no longer using its clinker; and the clinker used is transported through railways from the cement plant Cienfuegos; located $100 \mathrm{~km}$ and equipped with a dry process rotary kiln of high efficiency. The production strategy also foresees clay calcination at Siguaney in a retrofitted wet process cement kiln. This could enable

TABLE 7. Results of compressive strength of concrete made for prefabricated elements with OPC and LCC

\begin{tabular}{lccccc}
\hline Material & $\begin{array}{c}\text { Cement } \\
\text { consumption }\left(\mathbf{k g} / \mathbf{m}^{\mathbf{3}}\right)\end{array}$ & $\begin{array}{c}\text { Average compressive } \\
\text { strength at 3 d (MPa) }\end{array}$ & $\begin{array}{c}\text { Average compressive } \\
\text { strength at 7 d (MPa) }\end{array}$ & $\begin{array}{c}\text { Average compressive } \\
\text { strength at 28 d (MPa) }\end{array}$ & $\begin{array}{c}\text { Cement } \\
\text { performance* }\end{array}$ \\
\hline LCC & 360 & - & 21.0 & 31.4 & 0.9 \\
OPC & 360 & 20.4 & - & 33.2 & 0.9 \\
\hline
\end{tabular}

*Relation between the compressive strength obtained at 28 days in $\mathrm{kg} / \mathrm{cm}^{2}$ and the cement consumption. 
TABLE 8. $\quad \mathrm{CO}_{2}$ emissions vs. clinker factor in the cement production (calculated in reference (3))

\begin{tabular}{lcrrr}
\hline & & \multicolumn{3}{c}{ Clinker factor (\%) } \\
\cline { 3 - 5 } Phases of the productive process & Unitary value $\left(\mathbf{K g ~ C O}_{2} / \mathbf{t}\right)$ & $\mathbf{1 0 0} \%$ Clinker & $\mathbf{7 0} \% \mathbf{C l i n k e r}$ & $\mathbf{5 5 \%} \mathbf{C l i n k e r}$ \\
\hline Raw materials calcination $(\mathrm{CaO}$ y $\mathrm{MgO})$ & 502.0 & 502.0 & 351.4 & 276.1 \\
Fuel & 320.0 & 320.0 & 224.0 & 176.0 \\
Additions (calcined clay, limestone) & 380.0 & 0.0 & 38.2 & 57.2 \\
Grinding & 100.0 & 100.0 & 100.0 & 100.0 \\
Others & 60.0 & 60.0 & 60.0 & 60.0 \\
TOTAL & & $\mathbf{9 8 2 . 0}$ & $\mathbf{7 7 3 . 6}$ & $\mathbf{6 6 9 . 3}$ \\
Savings related to a clinker factor of $\mathbf{1 0 0} \%$ & & & $\mathbf{7 9} \%$ & $\mathbf{6 8} \%$ \\
\hline
\end{tabular}

using the existing infrastructure for production in Siguaney-calcining clay; grinding cement; storing; etc. - and yet achieve some degree of efficiency in the process.

Clay calcination is foreseen in two alternative scenarios:

1. Short term: Production of calcined clays in using an existent wet process rotatory kiln in Siguaney factory.

2. Long term: Production of calcined clays in an industrial retrofitted calciner to be set in Siguaney factory; operating with dry process.

$\mathrm{CO}_{2}$ emissions during cement manufacture were calculated by dividing the productive process in two phases: (i) clinker and clay calcination; and (ii) mixing and grinding of the clinker and additions.

During the calcination process; three main emission sources can be defined: a) Fossil fuels combustion; b) chemical decomposition of calcium carbonate $\left(\mathrm{CaCO}_{3}\right)$ and magnesium $\left(\mathrm{MgCO}_{3}\right)$ and c) electricity consumption. The methodology to estimate the $\mathrm{CO}_{2}$ emissions followed the recommendations of the Intergovernmental Panel for Climate Change; 2006 (IPCC) (38); whereas clinker (CK) production is multiplied by an emission factor. So; the $\mathrm{CO}_{2}$ emissions caused by the energy consumption ( $\mathrm{a}$ and $\mathrm{c}$ ); are calculated using the following formula [5]:

$\mathrm{CO}_{2}$ emissions $=$ Emission factor $*$ Consumption index $[5]$

Where:

$\mathrm{CO}_{2}$ emissions: $\mathrm{kg} \mathrm{CO}$ /tonne CK-Calcined clay Emission factor: $\mathrm{kg} \mathrm{CO}_{2}$ /unit of energy used Consumption index: unit of energy used/tonnes of CK-Calcined clay.

The dry process clinker production operates with pet-coke and the electricity is supplied by the National Energy System (NES) as energy sources. Table 9 presents the emissions associated to the energy consumption on the first stage of cement manufacture; mainly clinker production.
For clay calcination at cement plant Siguaney; crude oil was used and electricity was supplied by the National Energy System. Table 10 displays the emissions associated to energy consumption during clay calcination in the short and long term scenarios.

The emissions caused by the chemical decomposition of $\mathrm{CaCO}_{3}$ y $\mathrm{MgCO}_{3}$ contained in raw materials (grey limestone and clays); may be deduced through stoichiometry calculations with two different approaches:

a) By calculating the differences in the $\mathrm{CaO}$ and $\mathrm{MgO}$ content of the raw materials before been fed to the kiln and at the exit (CK or calcined clay) (39).

b) By assessing the contribution of each component of the paste to the total $\mathrm{CO}_{2}$ emissions; through the knowledge of the chemical composition of the minerals used in the materials at the entrance of the kiln and its $\mathrm{CaCO}_{3}$ and $\mathrm{MgCO}_{3}$ content.

The use of one or other approach is determined by the data availability; which helps to describe the chemical composition of the material; before and after processing it.

The authors chose to measure the differences between the $\mathrm{CaO}$ and $\mathrm{MgO}$ content of the materials while entering or exiting the kiln. The differences in the oxides content are converted by stoichiometry on the $\mathrm{CO}_{2}$ released.

The $\mathrm{CO}_{2}$ emissions due to the decarbonation of limestone were calculated for the conditions of Cienfuegos factory; which is the main clinker supplier for cement production in Siguaney. Table 11 presents the calculation of the emissions at the decarbonation of calcium and magnesium carbonate during clinker production at cement plant Cienfuegos.

The $\mathrm{CO}_{2}$ emissions in the phase of cement grinding; are associated with the electricity consumption in the ball mill; see Table 12. Other sources of emissions are considered negligible and thus discarded.

The final calculation of $\mathrm{CO}_{2}$ emissions is presented in Figure 6. The low carbon cement produced in non-optimized conditions during industrial trial; 
TABLE 9. $\mathrm{CO}_{2}$ emissions due to the energy consumption during the clinker production in Cienfuegos factory

\begin{tabular}{lcr}
\hline Consumption index (energy unit/t) & Emission Factor ( $\mathbf{k g ~ C O} /$ energy unit)* & $\mathbf{C O}_{2}$ emissions $(\mathbf{k g ~ C O} / \mathbf{t})$ \\
\hline Emissions due to fuel consumption (pet-coke) & $4.09\left(\mathrm{~kg} \mathrm{CO}_{2} / \mathrm{kg}\right.$ pet-coke) & 409.00 \\
100.00 (kg pet-coke) & & 29.69 \\
Emissions due to electricity consumption of NES & $744.00\left(\mathrm{~kg} \mathrm{CO}_{2} / \mathrm{MWh}\right)$ & 438.69 \\
0.0399 & & \\
Total $\mathrm{CO}_{2}$ released per energy consumption to produce 1ton of CK & \\
\hline
\end{tabular}

*Taken from the Clean Development Mechanism-UNEP Project of Cienfuegos factory, digital version 03.02.2006.

TABLE 10. $\mathrm{CO}_{2}$ emissions due to the energy consumption during clays calcination in Siguaney cement factory

\begin{tabular}{|c|c|c|c|}
\hline Scenarios & $\begin{array}{c}\text { Consumption index } \\
\text { (energy unit/t) }\end{array}$ & $\begin{array}{c}\text { Emission factor } \\
\text { (kg CO} / \text { energy unit) }\end{array}$ & $\begin{array}{c}\mathrm{CO}_{2} \text { emissions } \\
\left(\mathrm{kg} \mathrm{CO}_{2} / \mathrm{t}\right)\end{array}$ \\
\hline \multicolumn{4}{|c|}{ Emissions due to fuel combustion (cuban crude oil) } \\
\hline Short term (rotatory kiln-wet process) & $104.50^{* *}(\mathrm{~kg}$ crude $)$ & $3.28\left(\mathrm{~kg} \mathrm{CO}_{2} / \mathrm{kg}\right.$ crude oil $)$ & 342.76 \\
\hline Long term (industrial calciner) & $57.20 * * *$ & $3.28\left(\mathrm{~kg} \mathrm{CO}_{2} / \mathrm{kg}\right.$ crude oil $)$ & 187.62 \\
\hline \multicolumn{4}{|c|}{ Emissions due to electricity consumption of NES } \\
\hline Short term (rotatory kiln-wet process) & $0.0399 * *$ & $744.00\left(\mathrm{~kg} \mathrm{CO}_{2} / \mathrm{MWh}\right)$ & 29.69 \\
\hline Long term (industrial calciner) & $0.0239 * * *$ & $744.00\left(\mathrm{~kg} \mathrm{CO}_{2} / \mathrm{MWh}\right)$ & 17.81 \\
\hline
\end{tabular}

**Reduction of Cuban crude oil consumption for the calcined clay production related to clinker production are estimated in $40 \%$, due to the decrease of the calcination temperature and a reduction of $15 \%$ of electricity consumption because clay doesn't need to be processed in the paste mill.

***A reduction of $45 \%$ of the Cuban crude oil consumption and $40 \%$ of the electricity consumption are estimated related to the wet process production in the rotatory kiln, due to the reduction of the calcination temperature (the material is introduced with natural humidity) and the residence time in the calciner.

TABLE 11. Formula and data used for the calculation of $\mathrm{CO}_{2}$ released due the production of clinker by dry process

\begin{tabular}{|c|c|c|c|c|}
\hline \multicolumn{5}{|c|}{$\mathrm{CO}_{2}$ released $($ calcination $)=[0.785 *($ Out $\mathrm{CaO}-\mathrm{In} \mathrm{CaO})+1.092 *($ Out $\mathrm{MgO}-\mathrm{In} \mathrm{MgO})] / 100$} \\
\hline Out $\mathrm{CaO}(\%)$ & In $\mathrm{CaO}(\%)$ & Out MgO (\%) & In $\mathrm{MgO}(\%)$ & $\mathrm{CO}_{2}$ released for decarbonatation $\left(\mathrm{t} \mathrm{CO}_{2} / \mathrm{t} \mathrm{CK}\right)$ \\
\hline 65.09 & 0.00 & 1.63 & 0.00 & 0.53 \\
\hline
\end{tabular}

TABLE 12. $\mathrm{CO}_{2}$ emissions due to energy consumption during cement grinding

\begin{tabular}{lccc}
\hline Production & Consumption index $(\mathbf{M W h} / \mathbf{t})$ & Emission factor $\left(\mathrm{kg} \mathrm{CO}_{2} / \mathbf{M W h}\right)$ & $\mathbf{C O}_{2}$ emissions $(\mathrm{kg} \mathrm{CO} / \mathbf{t})$ \\
\hline Clinker/Calcined Clay* & 0.0465 & 744.00 & 34.60 \\
\hline
\end{tabular}

*It was considering that the grinding and mixing of the different types of cement have the same energy consumption.

reduces approximately $270 \mathrm{~kg} \mathrm{CO} /$ tonnes in relation to $\mathrm{OPC}(\mathrm{P}-35)$; this is approximately $31 \%$. Reduction in reference to traditional Cuban blended cement (PP-25) is in the range of $125 \mathrm{~kg} \mathrm{CO} /$ tonne. P-35 and PP-25 are both regularly produced at cement plant Siguaney.

In the projected long term scenario; the total estimated emissions for low carbon cement achieve emissions reduction higher than $300 \mathrm{~kg} \mathrm{CO} /$ tonne in relation to $\mathrm{P}-35$ and $200 \mathrm{~kg} \mathrm{CO} /$ tonne in relation to $\mathrm{PP}-25$. This represents more than $35 \%$ of reduction compared to business as usual practice.

Figure. 7 presents emissions and compressive strength at 28 days of LCC produced at the industrial trial; compared with reference values of cements P-35 and PP-25. This illustrates the idea that LCC; despite its very low clinker content which leads to low carbon emissions; does not compromise performance of cement; even compared with other cements produced industrially at the cement plant.

\section{CONCLUSIONS}

- There are alternatives available to move the current boundaries of clinker substitution for the production of blended cements through the use of ternary systems based on clinker; calcined clays and limestone. The principle behind this 


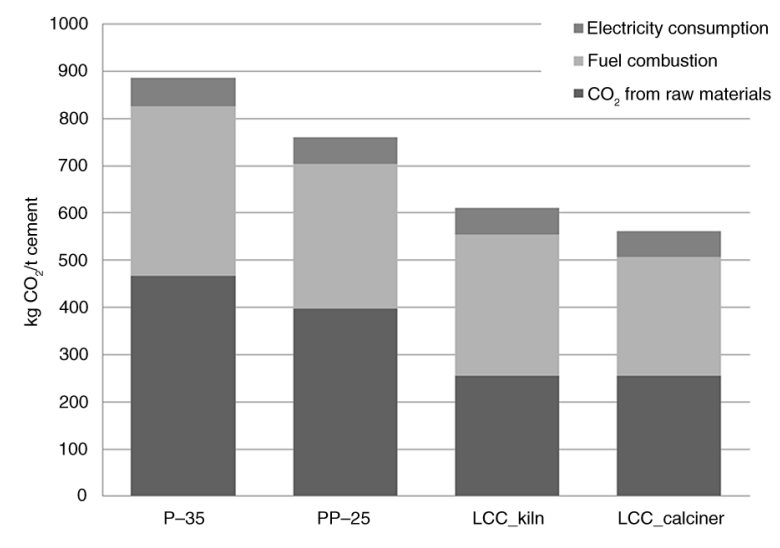

Figure 6. $\mathrm{CO}_{2}$ emissions associated to LCC production with $45 \%$ of SCM and compared to thre reference cements $\mathrm{P}-35$ and PP-25.

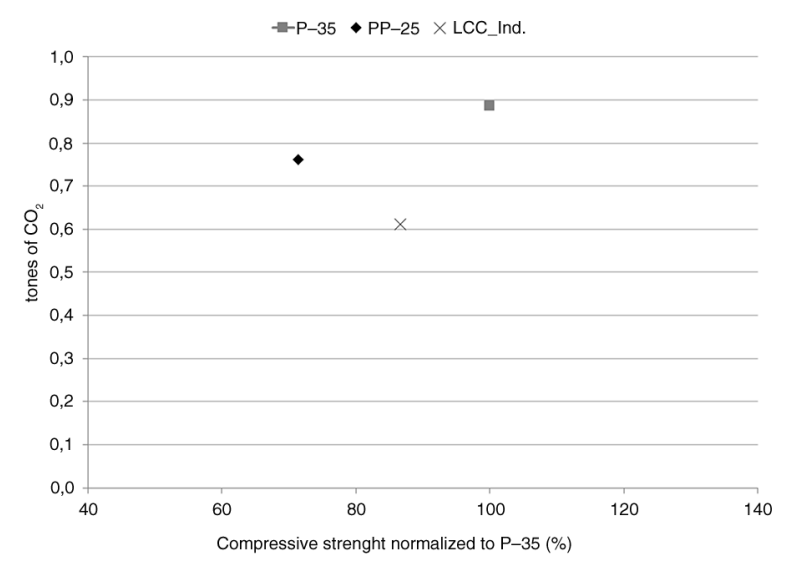

FIGURE 7. Relation between emissions of $\mathrm{CO}_{2} /$ ton cement and associated compressive strength of P-35; PP-25 and LCC produced in industrial trial.

proposal is the synergy between calcined clay and limestone; which allows increasing the reactivity of the SCMs and reduces clinker factor. This system is based on the use of medium grade kaolinite clay; and only small changes should be made to the production process. Reserves of medium grade clay and limestone are much higher than any other SCM.

- The industrial trial to produce cement with a clinker factor of $50 \%$ at the industrial scale has proven that the new system is very robust; while even in non-optimized conditions acceptable results have been achieved in terms of performance of the resulting material as cement; as well as in its applications in concrete.

- The new cementitious system could enable reduction on the emissions associated to the cement manufacture in the range of $25-35 \%$ related to business as usual practice. This reduction is based on replacing clinker; which is the main $\mathrm{CO}_{2}$ releaser; by a combination of materials whose emissions are negligible compared to clinker.

\section{ACKNOWLEDGEMENTS}

The authors would like to thanks the financial support from the Swiss National Science Foundation (SNSF) to this project and the Laboratoires des Matériaux de Construction (LMC) of the École Polytechnique Fédérale de Lausanne (EPFL) for offering their facilities. The authors would also like to acknowledge Siguaney cement factory for the technical and material support.

\section{REFERENCES}

1. U.S. Geological Survey. (2002) Mineral Commodity Summaries. http://minerals.usgs.gov/minerals/pubs/commodity/ cement.

2. Cembureau. (2010) Cembureau Report 2010. http://www. cembureau.eu/about-cement/key-facts-figures.

3. Habert, G.; Billard, C.; Rossi, P.; Chen, C.; Roussel, N. (2010) Cement production technology improvement compared to factor 4 objectives. Cem. Concr. Res. 40, 820-826. http://dx.doi.org/10.1016/j.cemconres.2009.09.031.

4. Purnell, P. (2013) The carbon footprint of reinforced concrete. Advances in Cement Research, 25 [1], 1-7. http:// dx.doi.org/10.1680/adcr.13.00013.

5. Schneider, M.; Romer, M.; Tschudin, M.; Bolio; H. (2011) Sustainable cement production-present and future. 41 [7], 642-650. http://dx.doi.org/10.1016/j.cemconres.2011. 03.019 .

6. Hendriks, C.A.; Worrell, E.; Martin, N.; Ozawa Meida, L.; de Jager, D.; Riemer, P. (1998) Emission reduction of greenhouse gases from the cement industry; in Fourth International Conference on Greenhouse Gas Control Technologies: Interlaken.

7. Damtoft, J.S.; Lukasik, J.; Herfort, D.; Sorrentino, D; Gartner, E.M. (2008) Sustainable development and climate change initiatives. Cem. Concr. Res. 38, 115-127. http:// dx.doi.org/10.1016/j.cemconres.2007.09.008.

8. Antoni, M.; Rossen, J.; Martirena, F.; Scrivener, K. (2012) Cement substitution by a combination of calcined clay and limestone. Cem. Concr. Res. 42 [12], 1579-1589. http:// dx.doi.org/10.1016/j.cemconres.2012.09.006.

9. Vizcaíno, L.; Antoni, M.; Alujas, A.; Scrivener, K.; Martirena, F. (2014) Calcined clays and Limestone as supplementary cementitious material for cements with low clinker content; under preparation for Mater. Construcc.

10. Fernández, L.R. (2009) Calcined Clayey Soils as a Potential Replacement for Cement in Developing Countries; in Faculté Sciences et Techniques de L'Ingeniur. PhD Thesis. Laboratory of Construction Materials. Ecole Polytechnique Federale de Lausanne: Lausanne; 1-178. https://infoscience. epfl.ch/record/130369? $\ln =$ fr.

11. Taylor, H.F.W. (1990); Cement Chemestry; Academia Press Inc; London; U.K.

12. Massazza, F. (1993) Pozzolanic cements. Cem. Concr. Comp. 15 [4], 185-214. http://dx.doi.org/10.1016/0958-9465 (93)90023-3.

13. Lothenbach, B.; Scrivener, K.L.; Hooton, R.D. (2011) Supplementary cementitious materials. Cem. Concr. Res. 41, 1244-1256. http://dx.doi.org/10.1016/j.cemconres.2010. 12.001 .

14. Fernández, R.; Martirena, F.; Scrivener, K.L. (2011) The origin of the pozzolanic activity of calcined clay minerals: a comparison between kaolinite; illite and montmorillonite. Cem. Concr. Res. 41 [41], 113-122. http://dx.doi.org/ 10.1016/j.cemconres.2010.09.013. 
15. Ambroise, J.; Maximilien, S.; Pera, J. (1994) Properties of Metakaolin blended cements. Advanced Cement Based Materials. 1 [4], 161-168. http://dx.doi.org/10.1016/10657355(94)90007-8.

16. Sabir, B.B.; Wild, S.; Bai, J. (2001) Metakaolin and calcined clays as pozzolans for concrete: a review. Cem. Concr. Comp. 23, 441-454. http://dx.doi.org/10.1016/S0958-9465 (00)00092-5.

17. De Weerdt, K. Ben Haha, M. Le Saout, G.; Kjellsen, K.O.; Justnes, H.; Lothenbach, B. (2001) Hydration mechanisms of ternary Portland cements containing limestone powder and fly ash. Cem. Concr. Res. 41, 279-291. http:// dx.doi.org/10.1016/j.cemconres.2010.11.014.

18. Moesgaard, M.; Herfort, D.; Steenberg, M.; Kirkegaard, L.F.; Yue, Y. (2011) Physical performances of blended cements containing calcium aluminosilicate glass powder and limestone. Cem. Concr. Res. 41 [3], 359-364. http:// dx.doi.org/10.1016/j.cemconres.2010.12.005.

19. Wild, S.; Khatib, J.; Jones, A. (1996) Relative strength; pozzolanic activity and cement hydration in superplasticized metakaolin concrete. Cem. Concr. Res. 26 [10], 1537-1544. http://dx.doi.org/10.1016/0008-8846(96)00148-2.

20. Ezziane, K.; Bougara, A.; Kadri, A.; Khelafi, H.; Kadri, E.H. (2007) Compressive strength of mortar containing natural pozzolan under various curing temperature. Cem. Concr. Comp. 29 [8], 587-593 http://dx.doi.org/10.1016/j. cemconcomp.2007.03.002

21. Ganesh Babou, K.; Sree Rama Kumar, V. (2000) Efficiency of GGBS in concrete. Cem. Concr. Res. 30 [7], 1031-1036. http://dx.doi.org/10.1016/S0008-8846(00)00271-4.

22. Lawrence, P.; Cyr, M.; Ryngot, E. (2005) Mineral admixtures in mortars effect of type; amount and fineness of fine. Cem. Concr. Res. 35, 1092-110. http://dx.doi.org/10.1016/j. cemconres.2004.07.004

23. Murat, M.; Comel, C. (1983) Hydration reaction and hardening of calcined clays and related minerals III. Influence of calcination process of kaolinite on mechanical strengths of hardened metakaolinite. Cem. Concr. Res. 13 [5], 631-637. http://dx.doi.org/10.1016/0008-8846(83) 90052-2.

24. Ambroise, J.; Murat, M.; Pera, J. (1985) Hydration reaction and hardening of calcined clays and related minerals V. Extension of the research and general conclusions.
Cem. Concr. Res. 15 [2], 261-268. http://dx.doi.org/10.1016/ 0008-8846(85)90037-7.

25. NC/CTN22; NC 96:2001 Cemento con adición activa. Especificaciones; Impreso en Cuba (2001).

26. NC/CTN22; NC 54-207:2000 Cemento - Ensayos físicomecánicos; Printed in Cuba (2000).

27. NC/CTN22; NC 54-206:2000 Cemento - Análisis químico de arbitraje; Printed in Cuba (2000)

28. NC/CTN22; NC EN 196-6:2007 Cemento Hidráulico. Método de Ensayo. Determinación de la finura y la superficie específica; Printed in Cuba (2007).

29. NC/CTN22; NC 506:2007 Cemento hidráulico. Método de ensayo. Determinación de la resistencia mecánica; Printed in Cuba (2007)

30. NC/CTN22; NC 524:2007 Cemento hidráulico. Método de ensayo. Determinación de la consistencia normal y tiempos de fraguado por aguja Vicat; Printed in Cuba (2007).

31. Vizcaíno, L.; Antoni, M.; Martirena, F.; Scrivener, K. (2014) Effect of fineness in clinker-calcined clays-limestone cements, accepted for publication at Advances in Cement Research, 2015

32. NC/CTN37; NC ISO 1920-2:2010 Ensayos al hormigón. Propiedades del hormigón fresco; Printed in Cuba (2010).

33. NC/CTN37; NC 167:2002 Hormigón Fresco. Toma de muestras; Impreso en Cuba (2002).

34. NC/CTN37; NC ISO 1920-3:2010. Ensayos de Hormigón Parte 3: Elaboración y curado de Probetas de Ensayos; Printed in Cuba (2010).

35. NC/CTN37; NC 724:2009 Ensayos del Hormigón. Resistencia del Hormigón en estado endurecido; Printed in Cuba (2009).

36. NC/CTN37; NC ASTM C 1231/C 1231M:2006 Hormigón. Refrentado de probetas cilíndricas utilizando placas no adheridas; Printed in Cuba (2006).

37. NC/CTN37; NC 2047:2010 Bloques huecos de hormigón Especificaciones; Printed in Cuba (2010).

38. Eggleston, H.S.; Buendia, L.; Miwa, K.; Ngara, T.; Tanabe, K. (2006) IPCC Guidelines for National Greenhouse Gas Inventories.; in National Greenhouse Gas Inventories Programme. http://www.ipcc-nggip.iges.or.jp.

39. WBCSD-CSI. (2005) The Cement $\mathrm{CO}_{2}$ and Energy Protocol-Version 3.0. 2005. http://www.wbcsdcement.org/. 